\title{
PERBANDINGAN EFEKTIVITAS PEMBERIAN REBUSAN JAHE MERAH DAN DAUN MINT DENGAN JERUK NIPIS DAN MADU TERHADAP MUAL MUNTAH PADA IBU HAMIL TRIMESTER I DI PUSKESMAS WAEPANA, NGADA, NTT.
}

\author{
Ursula Orcena Mau Soa ${ }^{1}$ Rizky Amelia ${ }^{2}$ Dhita Aulia Octaviani ${ }^{3}$ \\ E-mail address : chenmau212@gmail.com
}

\begin{abstract}
Nausea and vomiting is a normal experienced by $50-80 \%$ of first trimester pregnant women. Pregnant women condition is very vulnerable on drugs, so the pregnant women should usecomplementary therapies to reduce nausea and vomiting. Red ginger and mint leaves with lime and honey is herbal medicine can be used by first trimester pregnant women to reduce nausea and vomiting. This research intended to determine the effectiveness comparison of red ginger decoction and mint leaves with lime and honey to nausea and vomiting on first trimester pregnant women.

Quasi-Experiment method was used, two groups of pre-test and post-test design for this research. The sample in this research wasto 22 respondence of women at the first trimester pregnancy. Purposive Sampling was used for sampling. The data analysis used Mann-Whitney and Wilcoxon test. Based on the research result, the mean value on red ginger and mint before and after was 3.55 and 3.09, and the mean value of lime and honey before and after was 3.35 and 2.09 , with p-value of $(0.004)<\alpha(0.05)$ and $\mathrm{Z}$ count value: -3.014 . It means that there was difference between red ginger and mint leaves with lime and honey in reducing nausea and vomiting on first trimester pregnant women at Waepana Community Health Center, Ngada Regency, East Nusa Tenggara. With giving boiled ginger and mint more effective.

From the research results, it was expected that health workers need to provide health education to pregnant women about non-pharmacological methods to overcome nausea and vomiting which is by providing red ginger decoction and mint leaves with lime and honey at home.
\end{abstract}

Keywords : Red Ginger and Mint Leaves; Lime and honey; Nausea and Vomiting

1) Poltekkes Kemenkes Semarang

\section{Pendahuluan}

Kehamilan adalah suatu karunia yang begitu didambakan bagi seorang wanita. Setiap kehamilan merupakan proses yang alamiah. Selama kehamilan biasanya seorang wanita mengalami banyak keluhan, oleh karena itu ibu harus selalu memperhatikan dan menjaga kehamilan dari berbagai keluhan. kemudian dilanjutkan dengan pembelahan dan implantasi dalam Rahim (Baety, A 2011).

Kehamilan memengaruhi tubuh ibu secara keseluruhan dengan menimbulkan perubahan-perubahan fisiologi yang terjadi di seluruh sistem organ, sebagian besar perubahan pada tubuh ibu kebanyakan disebabkan oleh kerja hormonal. Perubahan ini terjadi akibat adanya ketidakseimbangan hormon progesteron dan estrogen yakni hormon kewanitaan yang ada di dalam 
tubuh ibu sejak terjadinya proses kehamilan (Mandriwati, 2008). Beberapa keluhan yang membuat ibu merasa tidak nyaman di antaranya adalah mual dan muntah (Smith,dkk, 2009).

Mual muntah (emesis gravidarum) merupakan hal yang umum terjadi pada awal kehamilan (Trimester I). Mual muntah biasanya terjadi pada pagi hari, oleh karena itu disebut juga Morning sickness, namun tidak menutup kemungkinan juga terjadi pada siang dan malam hari. Gunanegara mengungkapkan bahwa Mual muntah merupakan keluhan yang sering dialami oleh wanita hamil terutama trimester pertama dan dialami oleh 50-80\% wanita hamil.Penelitian ini sesuai dengan hasil penelitian yang dilakukan Supriyanto (2009), yang mengatakan bahwa 50-90\% wanita mengalami mual muntah pada trimester pertama dan sekitar 25\% wanita hamil yang mengalami masalah mual muntah memerlukan waktu untuk beristirahat dari pekerjaannya.Dari 360 wanita hamil, 2\% diantaranya mengalami mual muntah di pagi hari dan sekitar $80 \%$ mengalami mual muntah sepanjang hari. Kondisi ini biasanya bertahan dan mencapai puncak pada usia kehamilan 9 minggu. Namun demikian, sekitar 20\% kasus mual muntah akan berlanjut sampai kelahiran (Yulia, 2016).Salah satu penyebab mual muntah adalah karena kepekaan terhadap hormon kehamilan (Fitria R, 2013).

Pada trimester I sebanyak $66 \%$ wanita mengalami mual, $60-80 \%$ terjadi pada primigravida dan $40-60 \%$ pada multigravida. Namun demikian sekitar $12 \%$ ibu hamil masih mengalami mual muntah hingga usia kehamilan sembilan bulan (Suwarni,
2007). Perubahan saluran cerna dan peningkatan kadar Human Chorionic Gonadotropin (hCG) dalam darah menimbulkan beberapa keluhan yang membuat ibu merasa tidak nyaman saat kehamilan, diantaranya mual dan muntah. Emesis gravidarum ini menyebabkan penurunan nafsu makan sehingga terdapat perubahan keseimbangan elektrolit dengan kalium, kalsium dan natrium yang menyebabkan perubahan metabolisme tubuh (Parwitasari dkk, 2014).Emesis gravidarum dapat bertambah berat menjadi hiperemesis gravidarum yang menyebabkan ibu muntah terus menerus tiap kali minum atau makan, akibatnya tubuh ibu semakin lemah, pucat, dan frekuensi buang air kecil menurun drastis sehingga cairan tubuh berkurang dan darah menjadi kental (hemokonsentrasi) yang mengakibatkan peredaran darah melambat sehingga dapat menimbulkan kerusakan jaringan yang dapat membahayakan kesehatan ibu dan perkembangan janin yang dikandungnya (Hidayat, 2009)

Setiap wanita hamil akan memiliki derajat mual yang berbedabeda, ada yang tidak terlalu merasakan apa-apa, tetapi ada juga yang merasa mual dan ada yang merasa sangat mual dan ingin muntah setiap saat (Maulana, 2008). Kondisi ibu hamil sangat rentan terhadap penggunaan obat-obatan. Untuk itu sebaiknya dalam mengurangi mual muntah ibu hamil menggunakan terapi komplementer antara lain dengan buah-buahan dan tanaman herbal atau tradisional yang bisa dilakukan dengan mudah dirumah. Di Waepana, untuk mengatasi mual muntah selama kehamilan, masyarakat setempat biasanya menggunakan obat-obatan atau hanya didiamkan saja serta dengan 
beristirahat, sedangkan anjuran dari Puskesmas yaitu dengan cara makan porsi kecil tapi sering, bahkan setiap dua jam karena hal ini lebih mudah dipertahankan dibanding makan porsi besar tiga kali sehari; menghindari makanan yang susah dicerna; bila muntah dipagi hari, makan makanan kering seperti biskuit, sereal sebelum bangun dari tempat tidur atau makan makanan ringan tinggi protein sebelum tidur; jaga masukan cairan, makan makanan ringan tiap 2-3 jam, makan perlahan sampai makanan dikunyah sempurna, dan tetap duduk tegak selama 10-20 menit setelah makan untuk menghindari refluks lambung; hindari konsumsi air dalam jumlah besar dalam satu waktu, menghindari makanan pedas, gorengan, kopi, istirahat, hindari makanan beraroma kuat, menyengat dan makanan berlemak.

Terapi komplementer dengan menggunakan tanaman herbal yang bisa digunakan untuk mengurangi mual muntah selama kehamilan yaitu jahe, peppermint, lemon, dll (Ira Puspito, 2012). Fungsi farmakologis jahe salah satunya adalah antiemetik (anti muntah). Jahe juga merupakan stimulan aromatik yang kuat, disamping dapat mengendalikan muntah dengan meningkatkan gerakan peristaltik usus. Sekitar 6 senyawa yaitu minyak atsiri zingiberena (zingirona), zingiberol, bisabilena, kurkumen, gingerol dan flandrena didalam jahe telah terbukti memiliki aktivitas antiemetik (anti muntah) yang manjur (Fitria, 2013).

Penelitian yang dilakukan oleh Suwarni (2007) dalam Parwitasari (2014) tentang efektivitas minuman jahe dalam mengurangi emesis gravidarum pada ibu hamil trimester pertama, didapatkan hasil bahwa pemberian minuman jahe sangat efektif dalam mengatasi mual muntah ibu hamil trimester pertama. Setelah pemberian minuman jahe padakelompok intervensi, terdapat penurunan mual muntah. Jahe yang akan digunakan peneliti adalah jahe merah karena jahe merah mempunyai kandungan minyak atsiri yang tinggi dan rasa pedas daripada jahe gajah. Jenis jahe merah cocok untuk bahan dasar farmasi dan jamu atau diekstrak oleoresin dan minyak atsirinya. Penggunaan jahe merah juga digunakan dalam penelitian sebelumnya dalam bentuk Rebusan (Parwitasari, 2014)

Peppermint (Daun Mint) juga diketahui bisa menjadi obat yang aman dan efektif untukmengobati mual muntah pada ibu hamil (Elshabrina, 2013).Daun mint mengandung minyak atsiri yaitu menthol yang berpotensi memperlancar sistem pencernaan dan meringankan kejang perut atau kram karena memiliki efek anastesi ringan serta mengandung efek karminatif dan antispasmodik yang bekerja di usus halus pada saluran gastrointestinal sehingga mampu mengatasi atau menghilangkan mual muntah (Denise Tiran, 2008)

Jeruk nipis memiliki Flavonoid yang meningkatkan produksi empedu, asam, dan cairan pencernaan. Di mana kandungan flavonoid akan menetralkan cairan pencernaan asam, pengeluaran racun dalam tubuh (Atsariani, Burhan dan Zetra, 2010)

Terapi komplementer lainnya yang dapat mengurangi mual muntah pada ibu hamil trimester I adalah menggunakan madu Madu mengandung beberapa mineral yang penting bagi tubuh. Madu memiliki 
kandungan piridoksin sebagai antagonis reseptor dan manfaat lainya madu dapat membantu menjaga stamina dan kesehatan selama mengandung bayi dan membantu asupan gizi yang tinggi bagi pertumbuhan janin dalam kandungan (Wahyu, 2011)

Berdasarkan hasil studi pendahuluan yang dilakukan di Dinas Kesehatan Kabupaten Ngada pada tanggal 27 Desember 2017, data kejadian mual muntah atau tanpa muntah pada tiga tahun terakhir didapatkan hasil bahwa : tahun 2015 tertinggi pada bulan November 2015, sebanyak 30 orang dari 342 atau $(8,77 \%)$ ibu hamil trimester I dan pada bulan Desember menjadi 35 orang dari 342 atau (10,23\%) ibu hamil. Pada tahun 2016 terjadi pada bulan Januari 2016, sebanyak 28 orang dari 324 atau $(9,87 \%)$ ibu hamil trimester I dan pada bulan Februari menjadi 34 orang dari 324 atau $(10,47 \%)$ ibu hamil. Pada tahun 2017 terjadi pada bulan Juni 2017, sebanyak 31 orang dari 317 atau (9.86\%) ibu hamil trimester I dan pada bulan Agustus 2017 menjadi 37 orang dari 317 atau $(11,67 \%)$ ibu hamil. Studi pendahuluan yang dilakukan oleh peneliti kepada beberapa responden melalui wawancara pada tanggal 29 Desember 2017 diwilayah kerja Puskesmas Waepana dengan keluhan mual muntah sedang dari hasil wawancara 6 dari 8 orang ibu hamil yang mengalami atau merasakan mual muntah di pagi hari dengan frekuensi 3-4 x dalam sehari selama 24 jam.

Tujuan penelitian ini adalah untuk mengetahui perbandingan efektivitas pemberian rebusan jahe merah dan daun mint dengan jeruk nipis dan madu terhadap mual muntah pada ibu hamil trimester I di
Puskesmas Waepana, Kabupaten Ngada, NTT.

Berdasarkan uraian dari latar belakang di atas dan sesuai data yang disampaikan oleh Suwarni (2010), wanita hamil sebanyak $66 \%$ mengalami mual muntah pada awal kehamilan. Mual muntah pada timester pertama di masyarakat masih terjadi dan cara penanggulangannya sebagian besar masih menggunakan terapi farmakologis atau di diamkan saja. Akan lebih baik jika masyarakat khususnya ibu hamil mampu mengatasi masalah mual pada awal kehamilan dengan menggunakan terapi pelengkap non farmakologis terlebih dahulu.

\section{Metode}

Metode yang digunakan dalam penelitian ini yaitu Quasi Experiment dengan pendekatan pretest-posttest with design two eksperiment. Penelitian dilakukan pada bulan April 2018, sedangkan tempat penelitian dilakukan di Puskesmas Waepana, Kabupaten Ngada, NTT.Populasi dalam penelitian ini adalah seluruh ibu hamil trimester I di Puskesmas Waepana. Berdasarkan studi pendahuluan yang dilakukan pada bulan Maret 2018 jumlah ibu hamil trimester I adalah 35 orang.

Pengambilan sampel pada penelitian ini menggunakan rumus Lameshow 1990. maka diperoleh sampel minimal sebesar 9,8 dengan pembulatan maka diperoleh sampel sebesar 10 orang ditambah drop out $10 \%$ menjadi 11 orang untuk masingmasing kelompok perlakuan jahe merah dan daun mint dengan jeruk nipis dan madu. Penelitian ini menggunakan purposive sampling dengan kriteria inklusi.

Analisa data yang digunakan adalah analisa univariat dan bivariat. 
Analisa univariat dilakukan untuk menggambarkan karakteristik dari sampel responden. Analisa univariat yang akan digunakan oleh peneliti meliputi umur ibu, gravida, tingkat pendidikan, dan pekerjaan. Data yang ditampilkan dalam analisa univariat adalah distribusi frekuensi dari karakteristik responden (mean, median, modus, jumlah), standar deviasi, nilai maksimum dan minimum dari karakteristik responden.

Analisa bivariat dilakukan untuk mengetahui perbandingan antara variabel indenpenden dan variabel dependen. Uji normalitas data dengan menggunakan uji Shapiro-Wilk. Uji statistik yang digunakan yaitu uji non parametrik (Wilcoxon dan Mann Whitney).

III. Hasil dan Pembahasan

Tabel 1.Karakteristik Responden

\begin{tabular}{|c|c|c|c|c|c|c|c|}
\hline \multirow[t]{2}{*}{$\begin{array}{c}\text { Karakteristi } \\
\mathrm{k}\end{array}$} & $\begin{array}{l}\text { Kel } \\
\text { Eks } \\
\mathrm{n} \\
\text { Mer } \\
\text { Dau }\end{array}$ & $\begin{array}{l}\text { npok } \\
\text { erime } \\
\text { Jahe } \\
\text { h dan } \\
\text { Mint }\end{array}$ & \multicolumn{2}{|c|}{$\begin{array}{l}\text { Kelompok } \\
\text { Eksperimen } \\
\text { Jeruk Nipis } \\
\text { dan Madu }\end{array}$} & \multicolumn{2}{|c|}{ Jumlah } & \multirow[t]{2}{*}{$\begin{array}{l}p- \\
\text { value }\end{array}$} \\
\hline & $\mathrm{N}$ & $\%$ & $\mathrm{~N}$ & $\%$ & $\mathrm{~N}$ & $\%$ & \\
\hline Umur & & & & & & & \\
\hline Beresiko & 2 & 18.2 & 1 & 9.1 & 3 & 13.6 & \\
\hline $\begin{array}{l}\text { Tidak } \\
\text { Beresiko }\end{array}$ & 9 & 81.8 & 10 & 90.9 & 19 & 86.4 & 0.534 \\
\hline Total & 11 & 100 & 11 & 100 & 22 & 100 & \\
\hline Pendidikan & & & & & & & \\
\hline Dasar & 0 & 0 & 0 & 0 & 0 & 0 & \\
\hline Menengah & 7 & 63.6 & 5 & 45.5 & 12 & 54.5 & \\
\hline $\begin{array}{l}\text { Perguruan } \\
\text { Tinggi }\end{array}$ & 4 & 36.4 & 6 & 54.5 & 10 & 45.5 & 0.392 \\
\hline Total & 11 & 100 & 11 & 100 & 22 & 100 & \\
\hline Pekerjaan & & & & & & & \\
\hline $\begin{array}{l}\text { Tidak } \\
\text { Bekerja }\end{array}$ & 7 & 63.6 & 6 & 54.5 & 13 & 59.1 & 0.665 \\
\hline Bekerja & 4 & 36.4 & 5 & 45.5 & 9 & 40.9 & \\
\hline Total & 11 & 100 & 11 & 100 & 22 & 100 & \\
\hline Primi & 7 & 63.6 & 6 & 54.5 & 13 & 59.1 & \\
\hline Muliti & 4 & 36.4 & 5 & 45.5 & 9 & 40.9 & 0.665 \\
\hline Total & 11 & 100 & 11 & 100 & 22 & 100 & \\
\hline
\end{tabular}

Berdasarkan tabel 1 menunjukkan bahwa dari 22 responden yang diteliti, mayoritas karakteristik responden menurut umur ialah kelompok umur 20-35 tahun sebanyak 19 responden $(81,8 \%)$, pendidikan ibu adalah pendidikan menengah sebanyak 12 responden $(54,5 \%)$, pekerjaan ibu adalah tidak bekerja sebanyak 13 responden $(59,1 \%)$, dan status kehamilan ibu adalah primigravida sebanyak 13 responden $(59,1 \%)$.

Tabel 2.Distribusi Frekuensi Tingkat Mual Muntah pada Ibu Hamil Trimester I Sebelum dan Sesudah diberikan rebusan jahe merah dan daun mint.

\begin{tabular}{lcccc}
\hline \multirow{2}{*}{$\begin{array}{l}\text { Tingkat Mual } \\
\text { Muntah }\end{array}$} & \multicolumn{2}{c}{ Sebelum } & \multicolumn{2}{c}{ Sesudah } \\
\cline { 2 - 5 } & $\mathrm{F}$ & $\%$ & $\mathrm{~F}$ & $\%$ \\
\hline $\begin{array}{l}\text { Mual Muntah } \\
\text { Ringan (1- }\end{array}$ & 0 & 0 & 9 & 81,8 \\
2x/hari) & & & & \\
\hline $\begin{array}{l}\text { Mual Muntah } \\
\text { Sedang (3- }\end{array}$ & 11 & 100 & 2 & 18,2 \\
4x/hari) & & & & \\
\hline Total & 11 & 100 & 11 & 100 \\
\hline
\end{tabular}

Berdasarkan tabel 2. dapat diketahui frekuensi tingkat mual Muntah pada ibu hamil trimester I sebelum diberikan rebusan jahe merah dan daun mint semua responden mengalami mual muntah sedang sebanyak 11 orang $(100 \%)$, Sedangkan frekuensi tingkat mual muntah pada ibu hamil trimester I sesudah diberikan jahe merah dan daun mint sebagian besar responden mengalami mual muntah ringan sebanyak 9 orang $(81.8 \%)$, dan mual muntah sedang sebanyak 2 orang $(18.2 \%)$.

Tabel 3.Intensitas Mual Muntah pada Ibu Hamil Trimester I Sebelum diberikan Rebusan Jahe Merah Daun Mint dan Jeruk Nipis dan Madu.

\begin{tabular}{lcccc}
\hline \multicolumn{1}{c}{ Kelompok } & & \multicolumn{3}{c}{ Sebelum } \\
\cline { 3 - 5 } & Nean & Min & Maks \\
\hline $\begin{array}{l}\text { Jahe merah dan } \\
\text { daun mint }\end{array}$ & 11 & 3,54 & 3 & 4 \\
\hline $\begin{array}{l}\text { Jeruk nipis dan } \\
\text { madu }\end{array}$ & 11 & 3,36 & 3 & 4 \\
\hline
\end{tabular}


Berdasarkan tabel 3. menunjukkan bahwa dari 11 responden nilai mean tingkat mual muntah pada ibu hamil sebelum diberikan jahe merah dan daun mint adalah 3,54, dimana nilai mual terendah muntah adalah 3 dan tertinggi adalah 4. Sedangkan nilai mean pada tingkat mual muntah pada ibu hamil sebelum diberikan jeruk nipis dan madu adalah 3,36, dimana nilai mual muntah terendah adalah 3 dan tertinggi adalah 4 .

Tabel 4.Distribusi Frekuensi Tingkat Mual Muntah pada Ibu Hamil Trimester I Sebelum dan Sesudah diberikan jeruk nipis dan madu.

\begin{tabular}{lcccc}
\hline \multicolumn{1}{c}{ Tingkat Mual } & \multicolumn{2}{c}{ Sebelum } & \multicolumn{2}{c}{ Sesudah } \\
Muntah & F & $\%$ & F & $\%$ \\
\hline $\begin{array}{l}\text { Mual Muntah } \\
\text { Ringan (1- }\end{array}$ & 0 & 0 & 2 & 18,2 \\
2x/hari) & & & & \\
\hline $\begin{array}{l}\text { Mual Muntah } \\
\text { Sedang (3- } \\
\text { 4x/hari) }\end{array}$ & 11 & 100 & 9 & 81,8 \\
\hline Total & 11 & 100 & 11 & 100 \\
\hline
\end{tabular}

Berdasarkan tabel 4. dapat Frekuensi Tingkat mual Muntah pada ibu hamil trimester I sebelum diberikan jeruk nipis dan daun madu semua responden mengalami mual muntah sedang sebanyak 11 orang $(100 \%)$, Sedangkan frekuensi tingkat mual muntah pada ibu hamil trimester I sesudah diberikan jeruk nipis dan madu responden mengalami mual muntah ringan sebanyak 2 orang (18.2\%), dan mual muntah sedang sebanyak 9 orang $(81.8 \%)$.

Tabel 5.Intensitas Mual Muntah pada Ibu Hamil Trimester I Sesudah diberikan Rebusan Jahe Merah Daun Mint dan Jeruk Nipis dan Madu.

\begin{tabular}{lrrcc}
\hline & & \multicolumn{3}{c}{ Sesudah } \\
\cline { 3 - 5 } Kelompok & $\mathbf{N}$ & Mean & Min & Maks \\
\hline $\begin{array}{l}\text { Jahe merah } \\
\text { dan daun } \\
\text { mint }\end{array}$ & 11 & 3,09 & 2 & 4 \\
\hline $\begin{array}{l}\text { Jeruk nipis } \\
\text { dan madu }\end{array}$ & 11 & 2,09 & 1 & 3 \\
\hline
\end{tabular}

Berdasarkan tabel 5. menunjukkan bahwa dari 11 responden nilai mean tingkat mual muntah pada ibu hamil sebelum diberikan jahe merah dan daun mint adalah 3,09, dimana nilai mual muntah terendah adalah 2 dan tertinggi adalah 4. Sedangkan nilai mean pada tingkat mual muntah pada ibu hamil sesudah diberikan jeruk nipis dan madu adalah 2,09, dimana nilai mual muntah terendah adalah 1 dan tertinggi adalah 3 .

Tabel 6. Uji Normalitas data dengan Shapiro-Wilk

\begin{tabular}{lcccc}
\hline \multirow{2}{*}{ Kelompok } & \multicolumn{3}{c}{ Shapiro-Wilk } \\
\cline { 3 - 5 } & & Statistic & Df & Sig. \\
\hline $\begin{array}{l}\text { Jahe merah } \\
\text { daun mint }\end{array}$ & dan & 0,649 & 11 &, 000 \\
\hline $\begin{array}{l}\text { Jeruk nipis } \\
\text { madu }\end{array}$ & dan & 0,572 & 11 &, 000 \\
\hline
\end{tabular}

Berdasarkan tabel 6. dimana uji normalitas menggunakan uji Shapiro-Wilk pada rebusan jahe merah daun mint didapatkan nilai $\mathrm{p}=0,000$ dan jeruk nipis dan madu nilai $\mathrm{p}=0,000$ hal ini berarti $\mathrm{p}$ $<0,05$ yang menunjukkan bahwa data tidak berdistribusi normal, maka uji yang dilakukan adalah non parametrik yaitu Uji Wilcoxon.

Tabel 7. Perbedaan Intensitas Derajat Mual Muntah Sebelum dan Sesudah Pemberian Jahe Merah dan Daun Mint.

\begin{tabular}{|c|c|c|c|c|c|c|}
\hline $\begin{array}{l}\text { Kelompo } \\
\mathrm{k} \quad \text { Jahe } \\
\text { Merah } \\
\text { dan Daun } \\
\text { Mint }\end{array}$ & $\mathrm{N}$ & $\begin{array}{l}\text { Mea } \\
n\end{array}$ & $\begin{array}{l}\text { Mean } \\
\text { Perub } \\
\text { ahan }\end{array}$ & SD & $\mathrm{SE}$ & $\begin{array}{l}\text { P } \\
\text { Val } \\
\text { ue }\end{array}$ \\
\hline Pretest & 11 & 3,55 & & 0,52 & 0,16 & 0,02 \\
\hline Posttest & 11 & 3,09 & 0,46 & 0,70 & 0,21 & 5 \\
\hline
\end{tabular}

Berdasarkan Tabel 7.hasil analisis menggunakan uji Wilcoxon dapat disimpulkan bahwa pada perlakuan jahe merah dan daun mint, ada perbedaan tingkat intensitas muntahsecara siginfikan antara pre-test dan post-test ( $p$ value $=0,025>\alpha=0,05$ ). 
Tabel 8.Perbedaan Intensitas Derajat Mual Muntah Sebelum dan Sesudah Pemberian Jeruk nipis dan Madu.

\begin{tabular}{|c|c|c|c|c|c|}
\hline $\begin{array}{l}\text { Kelompok } \\
\text { Jeruk nipis } \\
\text { dan Madu }\end{array}$ & $\mathrm{N}$ & Mean & $\begin{array}{l}\text { Mean } \\
\text { Perubahan }\end{array}$ & SD & $\begin{array}{c}\mathrm{P} \\
\text { Value }\end{array}$ \\
\hline Pretest & 11 & 3,36 & & 0,50 & 0,002 \\
\hline Posttest & 11 & 2,09 & 1,27 & 0,54 & \\
\hline
\end{tabular}

Berdasarkan Tabel 8. hasil analisis menggunakan uji Wilcoxon dapat disimpulkan bahwa pada perlakuan jeruk nipis dan madu , ada perbedaan tingkat intensitas muntahsecara siginfikan antara pre-test dan post-test ( $p$ value $=0,002>\alpha=0,05)$. Dari hasil tersebut maka pemberian perlakuan berpengaruh signifikan dalam menurunkan intensitas mual.

Tabel 9. Perbandingan Intensitas Derajat Mual Muntah Sesudah (Posttest) Pemberian Rebusan Jahe Merah Daun Mint dan Jeruk Nipis dan Madu.

\begin{tabular}{|c|c|c|c|c|c|}
\hline $\begin{array}{l}\text { Kelom } \\
\text { pok }\end{array}$ & $\begin{array}{l}\text { Mea } \\
n\end{array}$ & $\begin{array}{l}\text { Mean } \\
\text { Differ } \\
\text { ence }\end{array}$ & $\begin{array}{l}95 \% \quad \mathrm{Cl} \\
\text { (Upper- } \\
\text { Lower) }\end{array}$ & $\begin{array}{l}\text { Mean } \\
\text { Rank }\end{array}$ & $\begin{array}{l}\mathrm{P} \\
\text { Value }\end{array}$ \\
\hline $\begin{array}{l}\text { Jahe } \\
\text { Mint }\end{array}$ & 3,09 & \multirow[t]{2}{*}{-1} & $2,94-2,33$ & 15,36 & \multirow[t]{2}{*}{0,004} \\
\hline $\begin{array}{l}\text { Jeruk } \\
\text { Madu }\end{array}$ & 2,09 & & & 7,64 & \\
\hline
\end{tabular}

Setelah dilakukan uji MannWhitney berdasarkan dari tabel hasil statistik didapatkan nilai $\mathrm{p}=0,004$. Dengan demikian nilai $\mathrm{p}$ lebih kecil dari $\alpha$ atau 0,05 sehingga Ho ditolak dan $\mathrm{Ha}$ diterima, maka ada perbedaan antara rebusan jahe merah dan daun mint dengan jeruk nipis dan madu dalam penurunan mual muntah pada ibu hamil trimester I di Puskesmas Waepana, Kabupaten Ngada, NTT.

\section{Karakteristik Usia Responden}

Berdasarkan hasil penelitian yang telah dilakukan di Puskesmas Waepana, didapatkan hasil usia responden terbanyak berada pada rentang umur 20-35 tahun $(86,4 \%)$ yang mengalami mual muntah.
Hasil penelitian ini sesuai dengan penelitian yang telah dilakukan oleh (Mariantari, 2014) tentang dukungan suami, usia ibu dan gravida terhadap kejadian emesis gravidarum dimana sebanyak $73,6 \%$ responden pada penelitiannya berusia 20-35 tahun.Kesimpulannya beberapa penelitian menyebutkan semakin tua usia seseorang maka, semakin jarang dia akan mengalami mual muntah. Hal ini disebabkan karena usia tua telah mempunyai pengalaman dalam mengatasi mual muntah, sedangkan pada usia muda belum mampu mengatasi karena sebagian besar merupakan kahamilan pertama (Putri dan Andiani,2017). Hasil penelitian ini menunjukkan bahwa usia responden masuk dalam kategori reproduksi sehat.

Pendidikan terakhir ibu sebagian besar adalah pendidikan menengah sebanyak 12 responden (54,5\%). Hasil penelitian ini sesuai dengan penelitian yang dilakukan Henny (2012) hubungan antar status gravida dengan kejadian emesis gravidarum pada ibu hamil trimester I yang menyimpulkan bahwa pendidikan sangat berpengaruh terhadap gejala mual muntah karena kurangnya informasi tentang kehamilan terutama primigravida semester I. Tingkat pendidikan berhubungan dengan kemampuan menerima informasi kesehatan dari media massa dan petugas kesehatan.

Hasil penelitian menunjukkan bahwa sebagian besar responden tidak bekerja,yaitu sebanyak 13 responden $(59,1 \%)$. Hal tersebut sesuai dengan penelitian yang dilakukan Putri (2017), bahwa $97 \%$ responden pada penelitiannya tidak bekerja atau ibu rumah tangga.Ibu hamil yang bekerja dengan layak akan memiliki tingkat sosial ekonomi yang baik, sehingga dapat memenuhi kunjungan pemeriksaan kahamilan sesuai petunjuk petugas kesehatan (Putri dan Andiani,2017)

Berdasarkan karakteristik paritas, sebagian besar responden adalah 
primigravida yaitu sebanyak 13 responden $(59,1 \%)$. Gravida juga dapat memengaruhi kejadian mual muntah. Peningkatan mual muntah terjadi pada perempuan yang baru pertama kali mengalami kehamilan(primigravida dibandingkan wanita yang telah mengalami beberapa kali kehamilan (multigravida). Hal ini disebabkan oleh perbedaan produksi hormon kehamilan pada kedua kelompok tersebut. Tetapi dalam beberapa kasus, gejala mual muntah dapat digunakan sebagai cara menarik perhatian atau sebagai cara meminta bantuan mengenai masalah kehidupan wanita.

Intensitas Mual muntah ibu hamil Trimester I sebelum dan sesudah diberikan perlakuan.

Berdasarkan hasil penelitian pada tabel 3. yang didapat dari 11 responden di Puskesmas Waepana menunjukkan bahwa nilai mean tingkat mual muntah pada ibu hamil sebelum diberikan jahe merah dan daun mint adalah 3,54, dimana nilai terendah mual muntah adalah 3 dan tertinggi adalah 4 . Sedangkan nilai mean pada tingkat mual muntah pada ibu hamil sesudah diberikan jahe merah dan daun mint adalah 3,36, dimana nilai mual muntah terendah adalah 3 dan tertinggi adalah 4. Hasil penelitian juga menunjukkan bahwa tingkat mual muntah pada ibu hamil sebelum diberikan jahe merah dan daun mint adalah semua responden mengalami mual muntah sedang sebanyak 11 orang (100\%), Sedangkan frekuensi tingkat mual muntah pada ibu hamil trimester I sesudah diberikan jahe merah dan daun mint sebagian besar responden mengalami mual muntah ringan sebanyak 9 orang $(81.8 \%)$, dan mual muntah sedang sebanyak 2 orang $(18.2 \%)$. Tingkat mual Muntah pada ibu hamil trimester I sebelum diberikan jeruk nipis dan daun madu semua responden mengalami mual muntah sedang sebanyak 11 orang $(100 \%)$, Sedangkan frekuensi tingkat mual muntah pada ibu hamil trimester I sesudah diberikan jeruk nipis dan madu responden mengalami mual muntah ringan sebanyak 2 orang (18.2\%), dan mual muntah sedang sebanyak 9 orang $(81.8 \%)$.

Jahe juga merupakan stimulan aromatik yang kuat, disamping dapat mengendalikan muntah dengan meningkatkan gerakan peristaltik usus. Beberapa studi menyebutkan bahwa jahe mempunyai efek yang bermanfaat terhadap pencegahan kanker, mual dan muntah saat kehamilan, mual muntah pada pasien kemoterapi dan mual mpuntah setelah tindakan operasi (Amelia dan Isna,2017)

Peppermint (Daun Mint) mengandung minyak atsiri yaitu menthol yang berpotensi memperlancar sistem pencernaan dan meringankan kejang perut atau kram karena memiliki efek anastesi ringan serta mengandung efek karminatif dan antispasmodik yang bekerja di usus halus pada saluran gastrointestinal sehingga mampu mengatasi atau menghilangkan mual muntah (Denise, 2008)

Jeruk nipis memiliki Flavonoid yang meningkatkan produksi empedu, asam, dan cairan pencernaan. Di mana kandungan flavonoid akan menetralkan cairan pencernaan asam, pengeluaran racun dalam tubuh (Atsariani,Burhan dan Zetra,2010).

Madu adalah satu-satunya sumber pemanis yang dikenal dan sudah digunakan sebagai pengobatan. Madu mengandung beberapa mineral yang penting bagi tubuh. Sejumlah kandungan zat tersebut mempunyai manfaat untuk ibu hamil diantaranya mengatasi morning sickness.

Hal ini didukung oleh penelitian Parwitasari (2014), dengan judul penelitian Perbandingan efektifitas pemberian rebusan jahe merah dan daun mint terhadap mual muntah pada ibu hamil trimester I di Puskesmas Garuda. Berdasarkan hasil uji statistik dengan menggunakan uji wilcoxon yang diperoleh p-value $(0,000)<\alpha(0,05)$. Hal ini berarti 
terdapat perbedaan signifikan antara ratarata intensitas derajat mual muntah sebelum dan sesuddah diberikan rebusan jahe, sedangkan rata-rata intensitas derajat mual muntah ibu hamil sebelum dan sesudah diberikan rebusan daun mint diperoleh p-value $(0,003)<\alpha(0,05)$ dengan kesimpulan terdapat perbedaan rata-rata intensitas derajat mual muntah sebelum dan sesudah diberikan rebusan jahe dan daun mint pada ibu hamil.

Perbandingan Efektivitas Pemberian Rebusan Jahe Merah dan Daun Mint dengan Jeruk Nipis dan Madu Terhadap Penurunan Mual Muntah pada Ibu Hamil Trimester I di Puskesmas Waepana, Kabupaten Ngada, NTT.

Dari hasil hasil analisa uji statistik menggunakan uji Mann-Whitney menunjukkan bahwa nilai $\mathrm{p}=0,004$ dengan taraf signifikasi $\alpha=5 \%(0,05)$. Dengan demikian nilai $\mathrm{p}<0,05$ sehingga Ho ditolak dan Ha diterima, yang artinya ada perbedaan antara rebusan jahe merah dan daun mint dengan jeruk nipis dan madu dalam penurunan mual muntah pada ibu hamil trimester I di Puskesmas Waepana, Kabupaten Ngada, NTT.

Hasil uji menunjukkan peranan jahe merah dan daun mint dapat mengurangi mual muntah karena jahe merupakan bahan yang mampu mengeluarkan gas dari dalam perut, hal ini akan meredakan perut kembung. Peppermint (Daun Mint) juga diketahui bisa menjadi obat yang aman dan efektif untuk mengobati mual muntah pada ibu hamil (Elshabrina,2013).

Penyajian rebusan jahe merah dan daun mint dapat memberi rasa nyaman diperut sehingga dapat mengurangi mual muntah. Dosis jahe merah dan daun mint perlu diperhatikan dalam pembuatan rebusan jahe merah dan daun mint. Hasil temuan peneliti, dosis jahe merah dan daun mint peneliti berikan yaitu 2,5 gr, dan daun 3-5 lembar, dengan dosis tersebut tidak ada respoden yang mengalami keluhan kencang pada perut/ keluarnya darah yang merupakan efek samping dari konsumsi jahe selama kehamilan. Konsumsi jahe selama yang berlebihan selama kehamilan dapat menyebabkan abortus selama kehamilan. Sedangkan dosis jeruk nipis 30 mg dan madu 50 gram yang peneliti berikan beberapa responden mengatakan mengeluh merasa asam, namun ada beberapa responden mengeluh terlalu asam. Jeruk nipis dan madu membuat minuman terasa menyegarkan dan dapat mengurangi mual muntah ibu hamil trimester I. Hal tersebut dikarenakan buah jeruk nipis mengandung vitamin $\mathrm{C}$, serta madu yang mengandung piridoksin sebagai antagonis reseptor dan manfaat lainnya madu dapat membantu menjaga stamina dan kesehatan selama mengandung bayi dan membantu asupan gizi yang tinggi bagi pertumbuhan janin dalam kandungan.

Jeruk nipis dan madu memiliki manfaat untuk mengurangi mual muntah pada kehamilan.Jeruk nipis memiliki flavonoid dan madu juga mengandung piridoksin, kedua zat tersebut sebagai antagonis reseptor serotonin untuk mengurangi mual muntah pada kehamilan. Secara umum selama penelitian tidak ibu hamil yang melaporkan efek samping dari mengkonsumsi rebusan jahe merah dan daun mint dengan jeruk nipis dan madu. Rata-rata ibu menyukai rebusan jahe merah dan daun mint.

Pemberian rebusan jahe merah dan daun mint dengan jeruk nipis dan madu $1 \mathrm{x}$ sehari selama 4 hari terhadap ibu hamil trimester I dengan mual muntah dapat terjadi penurunan mual muntah, karena jahe merah dan daun mint mempunyai kandungan minyak atsiri yang mampu memblok serotin sehingga dapat menyegarkan dan memblok refleks muntah.Perpaduan Jeruk nipis dan madu sebagai antagonis reseptor serotonin untuk mengurangi mual muntah pada kehamilan. 


\section{Simpulan}

1. Hasil penelitian pada karakteristik responden menunjukkan bahwa : usia responden berkisar usia 20-35 tahun sebanyak 19 responden $(81,8 \%)$, dan menunjukkan usia responden masuk dalam kategori reproduksi sehat, Pendidikan responden yang paling banyak yaitu pendidikan menengah sebanyak 12 responden $(54,54 \%)$, hal ini menunjukkan bahwa pendidikan sangat berpengaruh terhadap gejala mual muntah karena kurangnya informasi tentang kehamilan terutama primigravida trimester I, Pekerjaan responden sebagian besar tidak bekerja sebanyak 12 responden $(54,54 \%)$, Paritas responden yang paling banyak yaitu gravida I sebanyak 12 responden $54,54 \%$ ).

2. Intensitas mual muntah sebelum diberikan Rebusan jahe merah dan daun mint menunjukkan distribusi frekuensi intensitas mual muntah sebelum pada kelompok eksperimen yang diberikan jahe merah dan daun mint dengan jeruk nipis pada kategori sedang terdapat sebanyak 22 responden (100\%).

3. Pemberian rebusan jahe merah dan daun mint pada ibu hamil trimester I nilai mean sebelum dan sesudah masing-masing 3.35 dan 3.09, sedangkan nilai mean pada jeruk nipis dan madu masing-masing 3.36 dan 2.09. Berdasarkan hasil uji Mann Whitney menunjukkan perbedaan yang signifikan setelah pemberian rebusan jahe merah dan daun mint dengan $\mathrm{p}$ value $0,004<0,05$ yang berarti bahwa adanya perbedaan yang signifikan antara kelompok perlakuan sehingga disimpulkan terdapat perbedaan yang signifikan setelah pemberian rebusan jahe merah dan daun mint dengan jeruk nipis dan madu.

4. Perbandingan sesudah antara kelompok pemberian rebusan jahe merah dan daun mint dengan jeruk nipis dan madu disimpulkan bahwa pemberian jahe merah dan daun mint lebih efektif dibandingkan jeruk nipis dan madu.

.Diharapkan dapat dijadikan sebagai bahan masukan bagi tenaga kesehatan dalam pelayanan kebidanan denganmenggunakan terapi komplementer dalam menurunkan mual muntah pada ibu hamil trimester I. Dan Puskesmas memberikan promosi kesehatan pada masyarakat tentang informasi kesehatan untuk lebih meningkatkan mutu pelayanan kesehatan khususnya pelayanan kebidanan dengan cara konseling dan mengajarkan kepada ibu hamil cara membuat rebusan jahe merah dan daun mint dengan jeruk nipis dan madu atau dengan terapi komplementer lainnya seperti sereh.

\section{Daftar Pustaka}

Amelia, R. \& Isna, S. Effectiveness of Dark Chocolate and Ginger on PainReduction Scale in Adolescent Dysmenorhea. J. Kebidanan6, 7381 (2017).

Atsariani, N. P. F, Burhan R.V. P Zetra, Y. Minyak Atsiri dari Kulit Buah Citrus Grandis, Citrus Aurantium (L) dan Citrus Aurantitolia (Rutaceac) sebagai Senyawa Antibakteri dan Insektisida dan Insektisida. (Institusi Teknologi 10 November, 2010).

Baety, A. . Biologi Reproduksi Kehamilan dan Persalinan. (Graha Ilmu, 2011)

Denise Tiran. Clinical Aromatherapy For Pregnancy and Childbirth. (Elsevier Churcill Livingstone, 2008).

Elshabrina. Dahsyatnya Daun Obat Sepanjang Masa. (Cemerlang Publising, 2013).

Fitria, R. Efektifitas jahe untuk 
menurunkan mual muntah pada kehamilan trimester I. J. Matern. neonatal1, 55-66 (2013).

Gunanegara, R. F. et al.Perbandingan Efektivitas Kombinasi Ekstrak Jahe dan Piridoksin dengan Piridoksin Saja dalam Mengurangi Keluhan Mual Muntah pada Wanita Hamil. J. Kedokt. Maranatha9, 24-33 (2009).

Hidayati, R. Asuhan Keperawatan Pada Kehamilan Fisiologis dan Patologis. (Salemba Medika, 2009).

Ira Puspito. 92 Pengobatan Mandiri di Rumah Anda a - $z$ Gangguan Kesehatan Umum, Cara Mencegah dan Cara mengatasinya. (Bangkit, 2012).

Mandriwati. Penuntun Belajar Asuhan Kebidanan Ibu Hamil. (EGC, 2008).

Maulana, M. Penyakit Kehamilan dan Pengobatannya. (kata Hati, 2008).

Notoatmodjo. Metodologi Penelitian Kesehatan. (Rineka Cipta, 2010).

Parwitasari, C. D., Utami, S. \& Rahmalia, $\mathrm{S}$. Perbandinganefektivitas pemberian rebusan jahe dan daun mint terhadap mual muntah pada ibu hamil. (2014).

Putri, A. D., Andiani, D., Kesehatan, F. I., Parepare, U. M. \& Selatan, S. Efektifitas pemberian jahe hangat dalam mengurangi frekuensi mual muntah pada ibu hamil trimester I. 978-979 (2017).

Smith, dkk. Efektivitas Konsumsi Ekstrak Jahe dengan Frekuensi Mual Muntah pada Ibu Hamil di Wilayah Kerja Puskesmas Ungaran. (2009).
Available at: perpusnwu.web.id/karyailmiah/doc uments/3165.pdf. (Accessed: 15th November 2017)

Supriyanto. Faktor predisposisi kejadian Emesis Gravidarum pada Ibu Hamil Trimester I di RB YKWD. (2009). Available at: digilib.unimus.ac.id/download.php $=682$. (Accessed: 20th November 2017)

Suwarni. Hubungan Karakteristik Ibu Hamil Trimester I dengan Morning Sickness di Poliklinik Kebidanan dan Penyakit Kandungan Badan Pelayanan Kesehatahan RSU DR Zainoel Abidin Banda Aceh Tahun 2007. J. Keperawatan1, 50-59 (2010)

Wahyu, T. Khasiat Madu untuk Kesehatan. (2011)

Yulia Fauziyah. Obtetri Patologi. (Nuha Medika, 2016). 